\title{
Response of Black and White Plumage Strains of Commercial Cocks to Feed Restriction at Different Ages raised on Deep Litter System
}

Ogunlade JT, Olawumi SO*, Fajemilehin SOK, Dairo FAS, Ojo JO, Adelabu DB and Adebolu A Department of Animal Science, Ekiti State University P. M. B. 5363, Ado-Ekiti, Nigeria

\begin{tabular}{|c|c|}
\hline $\begin{array}{c}\text { Article History } \\
\text { Received: } 01.10 .2020 \\
\text { Accepted: } 15.10 .2020 \\
\text { Published: } 23.10 .2020 \\
\\
\text { Journal homepage: } \\
\text { http://www.easpublisher.com/easjals/ } \\
\end{array}$ & 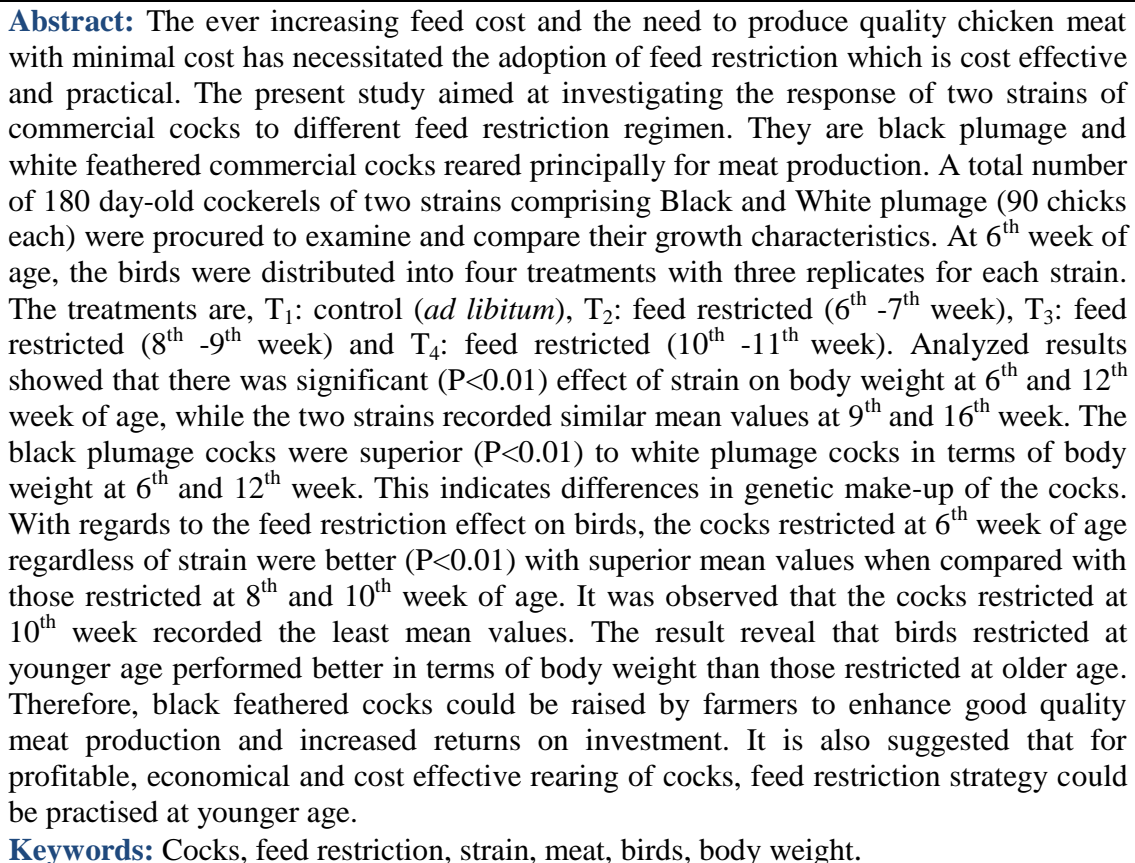 \\
\hline
\end{tabular}

Copyright (C) 2020 The Author(s): This is an open-access article distributed under the terms of the Creative Commons Attribution 4.0 International License (CC BY-NC 4.0) which permits unrestricted use, distribution, and reproduction in any medium for non-commercial use provided the original author and source are credited.

\section{INTRODUCTION}

In most developing countries, and Nigeria in particular, there is short supply of animal proteins leading to acute shortage in animal protein consumption. This inadequate supply and consumption results to malnutrition in children and other vulnerable groups. Poultry meat aside its tenderness and acceptability is cheaper when compared to other sources of meat. There is no taboo against its rearing and consumption, very easy to manage, simple housing and provides employment and quick returns on investment. Previous authors had documented strain differences on growth patterns of domestic chickens. Sahrael and Shariatmadari [1] and Benyi et al. [2] found significant strain differences in body weight gain, final body weight, feed intake and feed conversion ratio. In addition, Olawumi et al. [3] observed significant strain differences in growth traits of three strains of commercial broilers. And this was in agreement with previous authors $[4,5]$.
The high cost of producing a kilogram of poultry meat and products coupled with the reduction in profit margin are the major challenges in the industry [6]. It has been documented that feed accounts for 60$70 \%$ of the cost involved in poultry production [7]. In an attempt to reduce cost of producing a kilogram of broiler chicken, feed restriction has been suggested as a management tool designed to limit bird's access to feeds during a definite period of time which could be quantitative or qualitative [8]. Previous studies had used the concept of feed restriction in broilers to reduce the incidence of metabolic disorders and high mortality [9]. Previous reports had also shown that feed restriction helped in arterial oxygenation by reducing metabolic demands during critical periods of the life span of a bird [10] and enhanced efficiency of feed utilization, reduced feed cost and mortality rate [11].

There are different methods of feed restriction employed in broiler production in order to improve 
efficiency of feed utilization and weight gain, and these include intermittent feeding, skip-a-day feeding [12], and appetite suppression with glycolic acid [13], time of restriction [14], diet dilution [1] and quantitative feed restriction [15]. Olawumi et al. [3] reported significant effect of feed restriction on growth traits in broiler chickens. This was consistent with other previous studies $[16,16]$.

There is insufficient information in literature as regards the effect of feed withdrawal at different ages on growth characteristics of commercial cocks reared on deep litter system. The present investigation was therefore, undertaken to determine the response of two strains of cocks to feed restriction at different ages.

\section{MATERIALS AND METHODS}

The study was carried out at the Teaching and Research Farm, Ekiti State University, Ado-Ekiti from September, 2017 to January, 2018. Ado-Ekiti is situated along latitude $7^{0} 31^{1}$ and $7^{0} 49^{1}$ North of the Equator and longitude $5^{0} 71^{1}$ and $5^{0} 27^{1}$ East of the Greenwich meridian. The city falls under Derived Savannah zone. The city enjoys two separate seasonal periods namely, Rainy (May-October) and Dry (November-April) seasons.

\section{Source of experimental birds and feeding system}

A total number of 180 day-old cockerels of two strains comprising of Black and White plumage (90 chicks each) were procured to examine and compare their growth characteristics. The poultry environment was cleaned and free from weed, the brooding room and pens were washed and fumigated. Also the feeders and drinkers were washed and disinfected. The birds were raised on deep litter with the floor covered with wood shavings partitioned into two different units where both strains were raised separately in the brooding room.

They were kept under the same management conditions like space, light, temperature, ventilation and relative humidity. Fresh and clean water was available ad libitum.

The chicks were brooded for 4 weeks and were fed ad libitum with starter feeds having $3000 \mathrm{Kcal}$ $\mathrm{MEkg}^{-1}$, 22\% CP. Vaccination and other routine medications were carried out as and when due. From $8^{\text {th }}$ $-16^{\text {th }}$ week, the birds were given grower mash having $2500 \mathrm{KcalMEkg}^{-1}, 15 \% \mathrm{CP}$.

At $6^{\text {th }}$ week of age, the birds were distributed into four treatments with three replicates for each strain. The treatments applied are as follows:

$\mathrm{T}_{1}=$ both strains in this category were fed $a d$ libitum throughout the experiment

$\mathrm{T}_{2}=$ both strains in this category were feed restricted from $6^{\text {th }}-7^{\text {th }}$ week
$\mathrm{T}_{3}=$ both strains in this category were feed restricted from $8^{\text {th }}-9^{\text {th }}$ week

$\mathrm{T}_{4}=$ both strains in this category were feed restricted from $10^{\text {th }}-11^{\text {th }}$ week

\section{DATA COLLECTION \\ Data collected included the following:}

a. Body weight (bw): This was measured in grams for $6^{\text {th }}, 9^{\text {th }}, 12^{\text {th }}$ and $16^{\text {th }}$ week of age using a digital electronic scale (with maximum calibration of $5,000 \mathrm{~g}$ ). The body weights were measured early in the morning after starving the birds overnight.

All these conformation traits were measured using a tape rule.

- Breast girth (BRW) was measured across the keel bones from the left armpit to the right armpit.

- $\quad$ Thigh length (THL) was taken from the hock joint to the hinge joint.

- The tarso-meta tarsus (shank length) (SHL) was obtained by measuring from the hock joint to the base of the three toes.

- Wing length (WNL) was measured from the shoulder joint to the extremity of terminal phalanx.

- Others include body length and beak length

\section{DATA ANALYSIS}

The data collected were analysed by the analysis of variance technique in completely randomized design, while the differences between means were separated by Duncan New Multiple Range Test as per SAS [18].

The appropriate statistical model used was:

$$
\begin{aligned}
& Y_{i j k}=\mu+G_{i}+R_{j}+\varepsilon_{i j k} \\
& Y_{i j k}=\text { observation on } k^{\text {th }} \text { population, of } i^{\text {th }} \\
& \text { strain and } j^{\text {th }} \text { feed restriction } \\
& \mu=\text { common mean } \\
& \mathrm{G}_{\mathrm{i}}=\text { fixed effect of strain }(\mathrm{i}=2) \\
& \mathrm{R}_{\mathrm{j}}=\text { fixed effect of feed withdrawal }(\mathrm{j}=4) \\
& \varepsilon_{\mathrm{ijk}}=\text { error term }
\end{aligned}
$$

\section{RESULTS AND DISCUSSION}

Table 1 shows the least squares means regarding the strain effect on body weight and linear measurements of the commercial cocks at different ages regardless of the treatment employed. There was significant $(\mathrm{P}<0.01)$ effect of strain on body weight at $6^{\text {th }}$ and $12^{\text {th }}$ week of age, while the two strains recorded similar mean values at $9^{\text {th }}$ and $16^{\text {th }}$ week. The black plumage cocks are superior $(\mathrm{P}<0.01)$ to white plumage cocks in terms of body weight at $6^{\text {th }}$ and $12^{\text {th }}$ week. This indicates differences in genetic make-up of the cocks, and that the black feathered cocks have superior genetic constitution than their white mates. Therefore, black feathered cocks could be raised by farmers to enhance good quality meat production and increased returns on 
investment. Pertaining to wing length, the two strains recorded similar mean values, that is, no significant $(\mathrm{P}>0.05)$ differences between them. With regards to body length, significant $(\mathrm{P}<0.01)$ differences were observed between the two strains. The black feathered had higher mean values than the white cocks at all age groups. The obtained results were in agreement with the findings of Amao et al. who reported significant strain differences in body weight of broiler chickens at different age groups. Also, Ajayi and Ejiofor [4] and Olawumi et al. [5] observed significant differences in body weight of broiler chickens when measured at different ages.
The present data also reveal significant $(\mathrm{P}<0.01)$ strain differences between the two genotypes in other linear measurements such as breast girth, shank length, thigh length and beak length (Table 1). The black cocks had superior mean values than white cocks in all these morphometric traits. This implies that more meat could be obtained from raising the former than the latter. In addition, raising black cocks on commercial scale will no doubt increase the revenue of the farmers and improve their wellbeing and social status. These results were consistent with the findings of Amao et al. and Olawumi et al. [5] who reported significant strain differences in breast girth and shank length of broiler chickens.

Table-1: Least squares means showing the effect of Strain on Growth traits of Black and White feathered Cocks at different ages

\begin{tabular}{|c|c|c|c|c|c|c|c|c|}
\hline \multirow[t]{2}{*}{ Traits } & \multicolumn{2}{|c|}{$6^{\text {th }}$ week } & \multicolumn{2}{|c|}{$9^{\text {th }}$ week } & \multicolumn{2}{|c|}{$12^{\text {th }}$ week } & \multicolumn{2}{|c|}{$16^{\text {th }}$ week } \\
\hline & Black & White & Black & White & Black & White & Black & White \\
\hline \multirow[t]{2}{*}{ Body weight } & $317.52^{\mathrm{a}}$ & $296.08^{b}$ & 535.96 & 504.06 & $789.06^{\mathrm{a}}$ & $709.38^{b}$ & 1114.19 & 1076.10 \\
\hline & \pm 6.48 & \pm 6.48 & \pm 11.59 & \pm 11.59 & \pm 10.40 & \pm 10.40 & \pm 19.87 & \pm 19.87 \\
\hline \multirow[t]{2}{*}{ Wing length } & 11.98 & 11.78 & 16.14 & 16.00 & 18.60 & 18.49 & 19.80 & 19.60 \\
\hline & \pm 0.11 & \pm 0.11 & \pm 0.26 & \pm 0.26 & \pm 0.39 & +0.39 & \pm 0.21 & \pm 0.21 \\
\hline \multirow[t]{2}{*}{ Breast girth } & $10.27^{\mathrm{a}}$ & $9.96^{b}$ & 11.80 & 11.67 & $13.04^{\mathrm{a}}$ & $\overline{12.33^{b}}$ & 14.46 & 14.54 \\
\hline & \pm 0.09 & \pm 0.09 & \pm 0.14 & \pm 0.14 & \pm 0.10 & \pm 0.10 & \pm 0.09 & \pm 0.09 \\
\hline \multirow[t]{2}{*}{ Shank length } & 5.04 & 4.91 & $6.24^{\mathrm{a}}$ & $5.94^{b}$ & $7.29^{\mathrm{a}}$ & $6.80^{\mathrm{b}}$ & $8.18^{\mathrm{a}}$ & $7.91^{b}$ \\
\hline & +0.05 & +0.05 & +0.05 & +0.05 & +0.05 & +0.05 & +0.08 & +0.08 \\
\hline \multirow[t]{2}{*}{ Body length } & $30.13^{\mathrm{a}}$ & $28.73^{b}$ & $38.10^{\mathrm{a}}$ & $35.65^{b}$ & $48.95^{\mathrm{a}}$ & $43.12^{b}$ & $50.95^{\mathrm{a}}$ & $48.12^{b}$ \\
\hline & \pm 0.34 & \pm 0.34 & \pm 0.21 & +0.21 & \pm 0.30 & \pm 0.30 & \pm 0.39 & \pm 0.39 \\
\hline \multirow[t]{2}{*}{ Thigh length } & $11.62^{\mathrm{a}}$ & $10.99^{b}$ & $13.95^{\mathrm{a}}$ & $13.15^{b}$ & $16.45^{\mathrm{a}}$ & $14.89^{b}$ & $18.45^{\mathrm{a}}$ & $16.89^{b}$ \\
\hline & \pm 0.16 & \pm 0.16 & \pm 0.16 & \pm 0.16 & \pm 0.15 & \pm 0.15 & \pm 0.17 & \pm 0.17 \\
\hline \multirow[t]{2}{*}{ Beak length } & 1.49 & 1.44 & $1.72^{\mathrm{a}}$ & $1.60^{\mathrm{b}}$ & $2.09^{\mathrm{a}}$ & $1.92^{b}$ & $2.21^{\mathrm{a}}$ & $2.07^{b}$ \\
\hline & +0.02 & +0.02 & +0.02 & +0.02 & +0.02 & +0.02 & +0.03 & +0.03 \\
\hline
\end{tabular}

$\mathrm{Ab}$-means with different superscripts along rows are significantly different $(\mathrm{P}<0.01)$

In Table 2, there was significant $(\mathrm{P}<0.01)$ effect of feed restriction on body weight of cocks regardless of the strain. At $6^{\text {th }}, 9^{\text {th }}, 12^{\text {th }}$ and $16^{\text {th }}$ week of age, the control birds had higher mean values compared to all feed restricted birds. With regards to the feed restricted birds, the cocks restricted at $6^{\text {th }}$ week of age regardless of strain were better $(\mathrm{P}<0.01)$ with superior mean values when compared with those restricted at $8^{\text {th }}$ and $10^{\text {th }}$ week of age at all different age groups when measurements were carried out. It was observed that the cocks restricted at $10^{\text {th }}$ week recorded the least mean values. The result reveal that birds restricted at younger age performed better in terms of body weight than those restricted at older age. This implies that regardless of the strain of cocks, it is better that cocks be restricted when they are still young in order for them to attain an appreciable weight and to obtain maximum meat and profit from them. In addition, it was observed that only the cocks restricted at $6^{\text {th }}$ week attained 'catch-up' growth status, and were at the same weight level with those under control at $16^{\text {th }}$ week.
The results of linear measurements (Table 2) showed that the traits were significantly $(\mathrm{P}<0.01)$ affected by feed restriction strategies applied. Both body length, wing length and thigh length were all influenced by quantitative feed restriction at different age groups when measurements were carried out. The control and $6^{\text {th }}$ week restricted cocks were better and gave higher mean values in terms of meat parts than $8^{\text {th }}$ and $10^{\text {th }}$ week restricted cocks. This implies that restricting feed at younger age for cocks regardless of strain is economical, cost effective and practical. On the other hand, restricting feed at later ages impacted negatively on their body weight and meat proportions, and therefore, should not be practised if our objective is to increase meat production and maximize profit. The obtained results were consistent with the findings of Olawumi et al. [3] who reported significant differences in linear measurements of broiler chickens subjected to feed restriction at different age groups. 
Table-2: Least squares means showing the effect of Feed withdrawal at different ages on Growth traits of Black and White feathered Cocks at different ages

\begin{tabular}{|c|c|c|c|c|c|c|c|c|}
\hline $\begin{array}{l}\text { Age } \\
\text { (week) }\end{array}$ & Treatment & $\begin{array}{l}\text { Body } \\
\text { weight }\end{array}$ & $\begin{array}{l}\text { Wing } \\
\text { length }\end{array}$ & $\begin{array}{l}\text { Breast } \\
\text { girth }\end{array}$ & $\begin{array}{l}\text { Shank } \\
\text { length }\end{array}$ & $\begin{array}{l}\text { Body } \\
\text { length }\end{array}$ & $\begin{array}{l}\text { Thigh } \\
\text { length }\end{array}$ & $\begin{array}{l}\text { Beak } \\
\text { length }\end{array}$ \\
\hline \multirow[t]{4}{*}{$6^{\text {th }}$ week } & $\mathrm{T}_{1}$ & $\begin{array}{l}316.25 a \\
\pm 9.16\end{array}$ & $\begin{array}{l}11.72 \mathrm{~b} \\
\pm 0.15\end{array}$ & $\begin{array}{l}10.06 \mathrm{~b} \\
\pm 0.13\end{array}$ & $\begin{array}{l}4.96 \\
\pm 0.07\end{array}$ & $\begin{array}{l}28.62 b \\
\pm 0.48\end{array}$ & $\begin{array}{l}11.29 \\
+0.22\end{array}$ & $\begin{array}{l}1.49 \\
\pm 0.03\end{array}$ \\
\hline & $\mathrm{T}_{2}$ & $\begin{array}{l}259.58 b \\
+9.16\end{array}$ & $\begin{array}{l}11.81 \mathrm{~b} \\
+0.15\end{array}$ & $\begin{array}{l}9.64 \mathrm{c} \\
+0.13 \\
\end{array}$ & $\begin{array}{l}4.84 \\
+0.07\end{array}$ & $\begin{array}{l}27.94 \mathrm{~b} \\
+0.48\end{array}$ & $\begin{array}{r}11.06 \\
+0.22 \\
\end{array}$ & $\begin{array}{l}1.40 \\
+0.03\end{array}$ \\
\hline & $\mathrm{T}_{3}$ & $\begin{array}{l}311.42 \mathrm{a} \\
+9.16\end{array}$ & $\begin{array}{l}11.71 \mathrm{~b} \\
+0.15\end{array}$ & $\begin{array}{l}10.08 \mathrm{~b} \\
+0.13\end{array}$ & $\begin{array}{l}5.06 \\
+0.07 \\
\end{array}$ & $\begin{array}{l}30.1 \mathrm{a} \\
+0.48 \\
\end{array}$ & $\begin{array}{r}11.39 \\
+0.22 \\
\end{array}$ & $\begin{array}{l}1.47 \\
+0.03 \\
\end{array}$ \\
\hline & $\mathrm{T}_{4}$ & $\begin{array}{l}339.95 \mathrm{a} \\
+9.16\end{array}$ & $\begin{array}{l}12.27 \mathrm{a} \\
+0.15\end{array}$ & $\begin{array}{l}10.67 \mathrm{a} \\
+0.13\end{array}$ & $\begin{array}{l}5.04 \\
+0.07 \\
\end{array}$ & $\begin{array}{l}31.06 \mathrm{a} \\
+0.48\end{array}$ & $\begin{array}{r}11.48 \\
+0.22 \\
\end{array}$ & $\begin{array}{l}1.49 \\
+0.03\end{array}$ \\
\hline \multirow[t]{4}{*}{$9^{\text {th }}$ week } & $\mathrm{T}_{1}$ & $\begin{array}{l}550.04 a \\
+16.39 \\
\end{array}$ & $\begin{array}{l}27.40 \mathrm{a} \\
+0.36 \\
\end{array}$ & $\begin{array}{r}11.70 \\
+0.20 \\
\end{array}$ & $\begin{array}{l}5.98 \mathrm{~b} \\
+0.07 \\
\end{array}$ & $\begin{array}{l}28.30 \mathrm{a} \\
+0.30 \\
\end{array}$ & $\begin{array}{l}13.49 \mathrm{ab} \\
+0.22\end{array}$ & $\begin{array}{l}1.67 \\
+0.02\end{array}$ \\
\hline & $\mathrm{T}_{2}$ & $\begin{array}{l}540.63 a \\
\pm 16.39 \\
\end{array}$ & $\begin{array}{l}26.64 a \\
\pm 0.36 \\
\end{array}$ & $\begin{array}{r}11.43 \\
\pm 0.20 \\
\end{array}$ & $\begin{array}{r}6.02 \mathrm{~b} \\
\pm 0.07 \\
\end{array}$ & $\begin{array}{l}27.31 \mathrm{~b} \\
\pm 0.30 \\
\end{array}$ & $\begin{array}{l}13.32 \mathrm{~b} \\
\pm 0.22 \\
\end{array}$ & $\begin{array}{l}1.65 \\
+0.02 \\
\end{array}$ \\
\hline & $\mathrm{T}_{3}$ & $\begin{array}{l}477.08 b \\
+16.39 \\
\end{array}$ & $\begin{array}{l}25.40 \mathrm{~b} \\
+0.36\end{array}$ & $\begin{array}{r}11.75 \\
+0.20\end{array}$ & $\begin{array}{l}6.05 \mathrm{~b} \\
+0.07\end{array}$ & $\begin{array}{l}26.52 b \\
+0.30\end{array}$ & $\begin{array}{l}13.34 \mathrm{~b} \\
+0.22\end{array}$ & $\begin{array}{l}1.65 \\
+0.02 \\
\end{array}$ \\
\hline & $\mathrm{T}_{4}$ & $\begin{array}{l}12.29 \mathrm{ab} \\
\pm 16.39 \\
\end{array}$ & $\begin{array}{l}26.38 \mathrm{ab} \\
\pm 0.36\end{array}$ & $\begin{array}{r}12.07 \\
+0.20 \\
\end{array}$ & $\begin{array}{r}6.32 \mathrm{a} \\
+0.07 \\
\end{array}$ & $\begin{array}{l}25.39 c \\
\pm 0.30 \\
\end{array}$ & $\begin{array}{l}14.06 \mathrm{a} \\
+0.22 \\
\end{array}$ & $\begin{array}{l}1.68 \\
+0.02 \\
\end{array}$ \\
\hline \multirow[t]{4}{*}{$\begin{array}{l}12^{\text {th }} \\
\text { week }\end{array}$} & $\mathrm{T}_{1}$ & $\begin{array}{l}768.75 a \\
\pm 14.71\end{array}$ & $\begin{array}{l}32.11 \mathrm{ab} \\
+30.88\end{array}$ & $\begin{array}{l}12.59 \mathrm{~b} \\
+0.14\end{array}$ & $\begin{array}{l}7.25 \mathrm{a} \\
\pm 0.07 \\
\end{array}$ & $\begin{array}{l}32.02 \mathrm{a} \\
\pm 0.43 \\
\end{array}$ & $\begin{array}{l}16.15 \mathrm{a} \\
+0.21 \\
\end{array}$ & $\begin{array}{l}2.04 \mathrm{a} \\
\pm 0.02 \\
\end{array}$ \\
\hline & $\mathrm{T}_{2}$ & $\begin{array}{l}777.08 \mathrm{a} \\
+14.71 \\
\end{array}$ & $\begin{array}{l}33.56 \mathrm{a} \\
+30.88 \\
\end{array}$ & $\begin{array}{l}13.09 \mathrm{a} \\
+0.14\end{array}$ & $\begin{array}{r}7.23 a \\
+0.07 \\
\end{array}$ & $\begin{array}{l}31.50 \mathrm{a} \\
+0.43\end{array}$ & $\begin{array}{l}16.13 a \\
+0.21 \\
\end{array}$ & $\begin{array}{l}2.02 \mathrm{ab} \\
+0.02\end{array}$ \\
\hline & $\mathrm{T}_{3}$ & $\begin{array}{l}744.79 a b \\
\pm 14.71 \\
\end{array}$ & $\begin{array}{r}31.25 b \\
+30.88 \\
\end{array}$ & $\begin{array}{l}12.40 \mathrm{~b} \\
+0.14 \\
\end{array}$ & $\begin{array}{r}6.82 \mathrm{~b} \\
+0.07 \\
\end{array}$ & $\begin{array}{l}29.81 b \\
\pm 0.43 \\
\end{array}$ & $\begin{array}{l}15.34 b \\
+0.21 \\
\end{array}$ & $\begin{array}{l}2.00 \mathrm{ab} \\
+0.02 \\
\end{array}$ \\
\hline & $\mathrm{T}_{4}$ & $\begin{array}{l}706.25 b \\
+14.71\end{array}$ & $\begin{array}{r}30.88 \mathrm{~b} \\
+30.88\end{array}$ & $\begin{array}{l}12.68 \mathrm{ab} \\
+0.14\end{array}$ & $\begin{array}{l}6.87 \mathrm{~b} \\
+0.07\end{array}$ & $\begin{array}{l}30.79 a b \\
+0.43\end{array}$ & $\begin{array}{l}15.09 \mathrm{~b} \\
+0.21\end{array}$ & $\begin{array}{l}1.96 \mathrm{~b} \\
+0.02\end{array}$ \\
\hline \multirow[t]{4}{*}{$\begin{array}{l}16^{\text {th }} \\
\text { week }\end{array}$} & $\mathrm{T}_{1}$ & $\begin{array}{l}1145.67 \mathrm{a} \\
+28.10 \\
\end{array}$ & $\begin{array}{l}23.45 \mathrm{c} \\
+0.30 \\
\end{array}$ & $\begin{array}{r}14.50 \\
+0.13 \\
\end{array}$ & $\begin{array}{r}7.93 \mathrm{~b} \\
+0.12 \\
\end{array}$ & $\begin{array}{l}24.19 \mathrm{~b} \\
\pm 0.55\end{array}$ & $\begin{array}{l}12.63 \mathrm{~b} \\
+0.24 \\
\end{array}$ & $\begin{array}{r}2.20 \mathrm{a} \\
+0.04 \\
\end{array}$ \\
\hline & $\mathrm{T}_{2}$ & $\begin{array}{l}1120.75 \mathrm{ab} \\
+28.10\end{array}$ & $\begin{array}{l}26.81 \mathrm{a} \\
+0.30 \\
\end{array}$ & $\begin{array}{r}14.54 \\
+0.13 \\
\end{array}$ & $\begin{array}{l}8.30 \mathrm{a} \\
+0.12 \\
\end{array}$ & $\begin{array}{l}26.04 \mathrm{a} \\
+0.55\end{array}$ & $\begin{array}{l}14.20 \mathrm{a} \\
+0.24 \\
\end{array}$ & $\begin{array}{l}2.15 \mathrm{ab} \\
+0.04\end{array}$ \\
\hline & $\mathrm{T}_{3}$ & $\begin{array}{l}1065.79 \mathrm{ab} \\
+28.10\end{array}$ & $\begin{array}{l}25.63 b \\
+0.30\end{array}$ & $\begin{array}{r}14.63 \\
+0.13 \\
\end{array}$ & $\begin{array}{l}8.10 \mathrm{ab} \\
+0.12 \\
\end{array}$ & $\begin{array}{l}25.94 a \\
+0.55 \\
\end{array}$ & $\begin{array}{l}14.09 \mathrm{a} \\
+0.24\end{array}$ & $\begin{array}{l}2.13 \mathrm{ab} \\
+0.04\end{array}$ \\
\hline & $\mathrm{T}_{4}$ & $\begin{array}{l}1048.35 b \\
\pm 28.10 \\
\end{array}$ & $\begin{array}{l}25.65 b \\
\pm 0.30 \\
\end{array}$ & $\begin{array}{r}14.33 \\
+0.13 \\
\end{array}$ & $\begin{array}{r}7.85 \mathrm{~b} \\
+0.12 \\
\end{array}$ & $\begin{array}{l}25.56 a b \\
\pm 0.55 \\
\end{array}$ & $\begin{array}{l}13.77 \mathrm{a} \\
+0.24 \\
\end{array}$ & $\begin{array}{l}2.07 \mathrm{~b} \\
\pm 0.04 \\
\end{array}$ \\
\hline
\end{tabular}

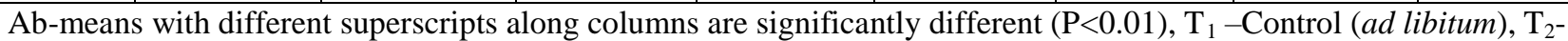
Restricted ( $6^{\text {th }}$ week $), \mathrm{T}_{3}$ - Restricted ( $8^{\text {th }}$ week $), \mathrm{T}_{4}$ - Restricted $\left(10^{\text {th }}\right.$ week $)$

\section{CONCLUSION}

The present investigation reveals significant differences in growth traits of two strains of commercial cocks. The black plumage cocks were superior to their white counterparts in body weight regardless of feed restriction strategies employed. In addition, significant strain differences were also observed with respect to body linear measurements. Pertaining to cocks performance subjected to feed restriction, birds restricted at $6^{\text {th }}$ week of age recorded higher mean values than those restricted at $8^{\text {th }}$ and $10^{\text {th }}$ week. The control birds and those restricted at $6^{\text {th }}$ week of age were superior in terms of body weight and body linear measurements. It is therefore, suggested that for profitable, economical and cost effective rearing of cocks, feed restriction strategy could be practised at younger age.

\section{ACKNOWLEDGEMENT}

The study was sponsored by TETfund agency (2014/2015 Intervention Fund), and the authors wish to express their sincere appreciation to the agency, and members of staff and management of Teaching and Research farm, Ekiti State University, Ado-Ekiti, for their support and cooperation during the course of research work.

\section{REFERENCES}

1. Sahraei, M., \& Shariatmadari, F. (2007). Effect of different levels of diet dilution during finisher period on broiler chickens performance and carcass characteristics. International Journal of Poultry Science, 6: 280-282.

2. Benyi, K., Acheampong-Boateng, O. Norris, D., Mathoho, M \& Mikasi, M. S. (2009). The response of Ross 308 and Hybro broiler chickens to early and late skip-a-day feed restriction. Tropical Animal Health and Production, 41(8): 1707-1713. 
3. Olawumi, S. O., Oyewole, B. O., Okpe, A. A., Ahutu, I. A. \& Ademakinwa, O. I. (2019). Comparison of strains and feed withdrawal durations on growth, haematological indices and serum biochemistry of broiler chickens at finisher phase. Nigerian Journal of Animal Science, 21(3): 274-280.

4. Ajayi, F.O., \& Ejiofor, O. (2009). Effects of genotype and sex interaction on growth and some development characteristic of Ross and Anak broiler strains in the high rain forest zone of Nigeria. Asian Journal of Poultry Science, 3:51-56

5. Olawumi, S., Ogunlade, T., \& Falemilehin, S. (2012). Production traits of broiler chicken strains fed ad libitum and raised on deep litter system in the humid tropics. Animal Research International, 9(1).

6. Yakubu, A., Egahi, J. O., Gwaza, D. S., Ahmadu, G. B., \& Thani, A. P. Growth Performance, Carcass Characteristics and Cost Benefits of Four Broiler Strains on Restricted Feeding Regimen in North Central Nigeria.

7. Sahraei, M. (2012). Feed restriction in broiler chickens production. Biotechnology in Animal Husbandry, 28(2), 333-352.

8. Olawumi, S. O. (2014). Carcass characteristics of broiler chicken strains fed different levels of feed restriction during eleven to seventeen days of age. South Pacific Journal of Technology and Science, 2(1), 261-268.

9. Balog, J. M., Anthony, N. B., Cooper, M. A., Kidd, B. D., Huff, G. R., Huff, W. E., \& Rath, N. C. (2000). Ascites syndrome and related pathologies in feed restricted broilers raised in a hypobaric chamber. Poultry Science, 79(3), 318-323.

10. Arce, J., Berger, M. \& Coello, C. L. (1992). Control of ascites syndrome by feed restriction techniques. The Journal of Applied Poultry Research, 1: 1-5.

11. Zubair, A. K., \& Leeson, S. (1996). Compensatory growth in broiler chickens: a review. World's Poultry Science, 52: 189-201.

12. Benyi, K., Acheampong-Boateng, O., \& Norris, D. (2011). Effects of strain and different skip-a-day feed restriction periods on the growth performance of broiler chickens. Tropical Animal Health and Production, 43(4): 871-876.

13. Pinchasov, V. Y., \& Jensen, L. S. (1989). Comparison of physical and chemical means of feed restriction in broiler chicks. Poultry Science, 68: 61-69.

14. Samara, M. H., Robinson, K. R. \& Smith, M. O. (1996). Interaction of feeding time and temperature and their relationship to performance of broiler breeder hens. Poultry Science, 75: 34-44.

15. Lee, K. H., \& Leeson, S. (2001). Performance of broilers fed limited quantities of feed or nutrients during seven to fourteen days of age. Poultry Science, 82: 446-454.

16. Razuki, W. M., Mukhlis, S. A., \& Hamad, R. F. (2007). Performance of three commercial broiler strains reared under hot and thermoneutral conditions. Iraqi Journal of Agriculture, 12: $92-$ 103.

17. Razuki, W. M., Mukhlis, S. A., Jasim, F. H., \& Hamad, R. F. (2011). Productive performance of four commercial broiler genotypes reared under high ambient temperature. International Journal of Poultry Science, 10(2): 87-92

18. Statistical Analysis System. (SAS, 2001). SAS Users Guide. Statistics, $8^{\text {th }}$ edition, SAS Institute Cary, NC, USA. 